九州大学学術情報リポジトリ

Kyushu University Institutional Repository

\title{
Distribution and Mobilization of Large Woody Debris in a Mountain Stream Network, Gangwon- do, South Korea
}

Kim, Suk-Woo

Department of Forest Resources, Kangwon National University

Otsuki, Kyoichi

Laboratory of Forest Ecosystem Management, Division of Forest Sciences, Department of AgroEnvironmental Sciences, Faculty of Agriculture, Kyushu University

Shinohara, Yoshinori

Faculty of Agriculture, Kyushu University

Chun, Kun-Woo

Department of Forest Resources, Kangwon National University

https://doi.org/10.5109/1526324

出版情報：九州大学大学院農学研究院紀要. 60 (1)，pp. 251-258，2015-02-27. Faculty of Agriculture, Kyushu University

バージョン :

権利関係 : 


\title{
Distribution and Mobilization of Large Woody Debris in a Mountain Stream Network, Gangwon-do, South Korea
}

\author{
Suk-Woo KIM ${ }^{1}$, Kyoichi OTSUKI, Yoshinori SHINOHARA ${ }^{2}$ and Kun-Woo CHUN ${ }^{1 *}$ \\ Laboratory of Forest Ecosystem Management, Division of Forest Sciences, \\ Department of Agro-Environmental Sciences, Faculty of Agriculture, \\ Kyushu University, Sasaguri, Fukuoka 811-2415, Japan \\ (Received October 31, 2014 and accepted November 14, 2014)
}

\begin{abstract}
Large woody debris (LWD) transport in headwater streams caused by forest disturbances such as wild fires, strong winds, and landslides affect the physical and ecological environment of the streams and become a disaster risk in downstream area. However, little attention has been given to LWD dynamics in South Korea where the forests comprise $63.7 \%$ of the land. As the first case study of LWD at the catchment scale in South Korea, we investigated the LWD dynamics according to the stream order in the experimental forests of Kangwon National University. The volume and number of LWD per unit channel area were $0.009 \mathrm{~m}^{3} / \mathrm{m}^{2}$ and 0.04 pieces $/ \mathrm{m}^{2}$ in the first order stream, $0.007 \mathrm{~m}^{3} / \mathrm{m}^{2}$ and 0.03 pieces $/ \mathrm{m}^{2}$ in the second order stream, and $0.004 \mathrm{~m}^{3} / \mathrm{m}^{2}$ and 0.01 pieces $/ \mathrm{m}^{2}$ in the third order stream, respectively, decreasing as the order increased. The average value $( \pm \mathrm{SD})$ of LWD piece length/channel width ratio was $0.61( \pm 0.62)$ in the first order stream, $0.33( \pm 0.34)$ in the second order stream, and $0.16( \pm 0.14)$ in the third order stream. The correlation between mid-diameter and length for coniferous and natural wood pieces was relatively high in the first order stream, but low in the second and third order streams, indicating downstream fragmentation. For the decay classes of LWD, class I to III gradually decreased, whereas class IV greatly increased as the stream order increased. LWD mobility was $60 \%$ for the first order stream, $56 \%$ for the second order stream, and $86 \%$ for the third order stream. Traveled distance of LWD was inversely related to the piece length/channel width ratio and increased more in the high order streams than in the low order streams. These results contribute to understanding the volume, distribution and mobilization of LWD within a stream network in Korean mountain catchments.
\end{abstract}

Key words: distribution, large woody debris, mobilization, Korean mountain catchment, stream order

\section{INTRODUCTION}

Large woody debris (LWD) entering headwater stream from the adjacent riparian zone caused by forest disturbance such as wildfire, windthrow, disease and landslide (Harmon et al., 1986) is a major component of channel bed, along with sand, cobbles and boulder, and significantly influences the physical and ecological environment of the stream. LWD contributes to deposition of sediment and nutrients (Swanson and Lienkaemper, 1978; Bilby and Ward, 1989; May and Gresswell, 2003; Faustini and Jones, 2003), formation of aquatic habitats (Bilby and Ward, 1989; Fausch and Northcote, 1992; Inoue and Nakano, 1998), increase of hydraulic resistance against water flowing (Lienkaemper and Swanson, 1987; Curran and Wohl, 2003; Wilcox and Wohl, 2006), dispersion of stream energy (Richimond and Fausch, 1995), and formation of steps and pools (Marston, 1982; Montgomery et al., 1995; Richmond and Fausch, 1995; Wohl et al., 1997). While studies on the geomorphic and ecological functions of LWD have been mainly conducted in North America for the past few decades, similar studies have been also reported from South America (Andreoli et al., 2007; Comiti et al., 2008; Iroumé et al., 2015), Europe (Piégay, 1993; Piégay and Gurnell, 1997; Comiti et al.,

\footnotetext{
1 Department of Forest Resources, Kangwon National University, Chuncheon 200-701, Republic of Korea

2 Faculty of Agriculture, Kyushu University, Fukuoka 812-8581, Japan

* Corresponding author (E-mail: kwchun@kangwon.ac.kr)
}

2006), East Asia (Miyabuchi et al., 1999; Haga et al., 2002; Shimizu, 2009; Chen et al., 2013), and Oceania (Mosley, 1981; Meleason et al., 2005). It indicates that LWD has long been recognized as an important component of stream in forested catchments across the globe. On the other hand, LWD is known to be a disaster risk causing direct and/or indirect damage to human life in downstream area by inducing floods that result from the reduction in the cross-sectional area of a river and destroying roads and bridges (Chun et al., 1997; Ishikawa, 2006).

The volume and distribution of LWD in a stream network strongly depend on the production or input mechanism, and channel morphology such as channel width and sinuosity (Bilby and Ward, 1989; Nakamura and Swanson, 1993; Nakamura et al., 2000), and LWD influences stream dynamics in spatial and temporal scales (Hyatt and Naiman, 2001; Hassan et al., 2005). Hence, the distribution and the geomorphic and ecological contribution of LWD may differ as it moves in the stream network from upstream (i.e., low order stream) to downstream (i.e., high order stream). For example, LWD often acts as a roughness element against the flow by forming steps or step-pools (Curran and Wohl, 2003) as it accumulates in narrow channels in low order streams without a significant floodplain. By contrast, in high order streams or large rivers, LWD forms pools by local and lateral scour, providing high shear stress locally (Abbe and Montgomery, 1996). While LWD plays a crucial role in releasing or depositing sediment in low order streams, its 
role is limited as it provides temporary storage zones in high order streams (Nakamura and Swanson, 1993). Accordingly, an understanding of LWD dynamics within a stream network and the resulting stream geomorphic, ecological, and hydrological processes are required for successful forest catchment management in a certain region.

Since mountainsides in Korea are steep and have shallow soil depth, shallow landslides are frequently occurred during the rainy season between June and September (Choi, 1986), resulting in a significant generation and output of LWD. Despite forest catchment management including LWD is critically important in South Korea where forests comprise $63.7 \%$ of the entire land area (Korea Forest Service, 2013) in terms of conservation of national land and management of water resources, little attention has been given to the characteristics of its distribution and mobilization in South Korea. Futhermore, thinned logs produced by the forest tending works to prevent forest disasters such as landslides are often left on forest hillslopes, thereby increasing potential to cause LWD disasters (Lee et al., 2007). Although LWD has been mostly recognized as a disaster risk in downstream areas, the positive functions of LWD have been also noticed in the increasing stream restoration projects for improving ecological functions of LWD as constructing materials for log-bed sill works (Kim et al., 2011). Accordingly, the characteristics of the distribution and dynamics of LWD that reflects forest behavior or disturbance should be understood to effectively reduce LWD disasters and successfully restore the ecosystem in the headwater streams.

The objectives of this study were (1) to quantify the distribution and amount of LWD, (2) to describe the characteristics of relative changes in the geometric dimensions and decay class of LWD, and (3) to examine the mobilization of LWD according to stream order in a mountain stream network, as the first case study on LWD at the catchment scale in South Korea.

\section{STUDY AREA}

The study site was the third order mountain catchment $\left(37^{\circ} 49^{\prime} 27^{\prime \prime} \mathrm{N}, 127^{\circ} 50^{\prime} 37^{\prime \prime} \mathrm{E}\right)$ within the experimental forests of Kangwon National University in Hongcheon-gun, Gangwon province, South Korea (Fig. 1). The study catchment area was $1.4 \mathrm{~km}^{2}$ and the altitude ranges from $350 \mathrm{~m}$ to $550 \mathrm{~m}$ above sea level. The climate is a temperate climate with four distinct seasons. According to the data from the Hongcheon weather sta- tion of Korea Meteorological Administration, the mean annual temperature was $10^{\circ} \mathrm{C}$ and the mean annual precipitation was $1501 \mathrm{~mm}$ during the past decade (20042013). About $75 \%$ of the annual precipitation was concentrated in the rainy seasons from June to September. The geology was mostly granite and granite gneiss, and the soil layer was mostly composed of the loam and sandy loam from the weathered granites (Chun et al., 2010). The forest was composed of 58\% Pinus koraiensis (plantation), 34\% broad-leaved trees (native), 7\% Larix kaempferi (plantation) and $1 \%$ mixed-tree species. $P$. koraiensis dominated most of the hillslope adjoining the stream banks, with a steep incline more than $35^{\circ}$.

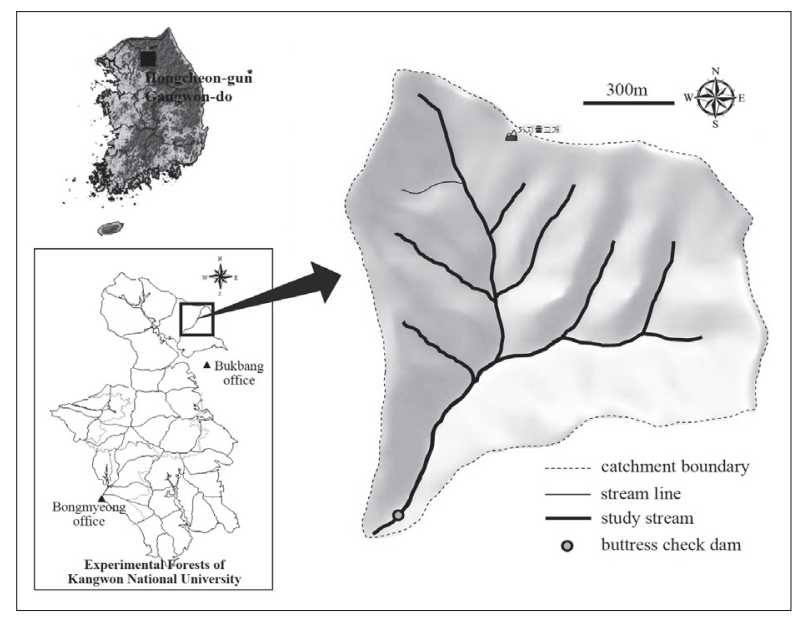

Fig. 1. Location map of the study area.

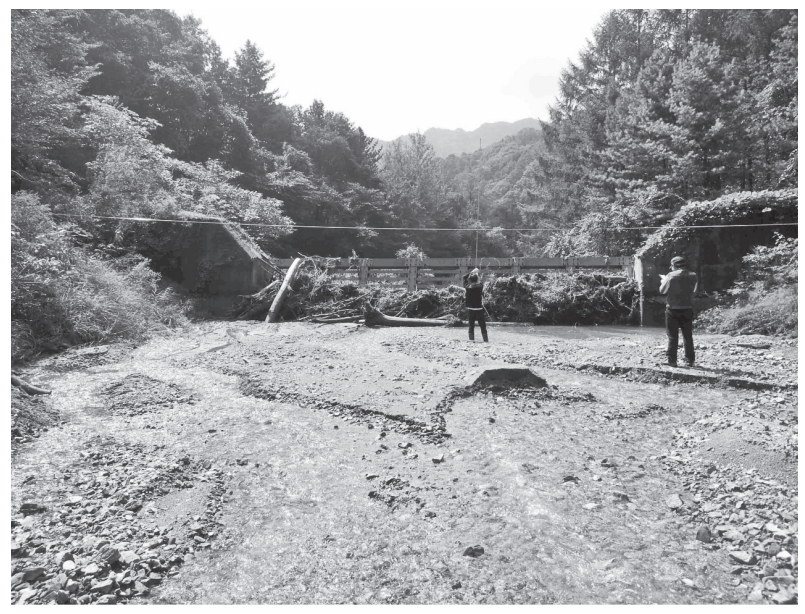

Fig. 2. LWD trapped by buttress check dam at the outlet of the catchment (16 September 2013).

Table 1. Characteristics of the study streams

\begin{tabular}{ccccc}
\hline Stream order & Number of streams & $\begin{array}{c}\text { Total length } \\
(\mathrm{m})\end{array}$ & $\begin{array}{c}\text { Mean bankfull width } \\
(\mathrm{m})\end{array}$ & $\begin{array}{c}\text { Mean channel slope } \\
(\mathrm{m} / \mathrm{m})\end{array}$ \\
\hline 1st & 8 & 2119 & 7.9 & 0.27 \\
2nd & 2 & 1193 & 11.7 & 0.17 \\
3rd & 1 & 500 & 23.2 & 0.08 \\
\hline
\end{tabular}


Total length of study reaches was $3812 \mathrm{~m}$, composed of $2119 \mathrm{~m}$ of first order stream, $1193 \mathrm{~m}$ of second order stream, and $500 \mathrm{~m}$ of third order stream. The geomorphic characteristics of study reaches are presented in Table 1 . The channel bed of study reaches was mostly composed of gravels and cobbles (mean grain size of $68.5 \mathrm{~mm}$ ) along with occasional boulders and bedrock outcrops (Chun et al., 2010).

In the study area, LWD mainly enters the stream channels through bank failure, windthrow, and infrequent hillslope collapse. Sediment and LWD were being frequently released downstream during torrential rains in summer, and therefore one buttress check dam was constructed at the outlet of the catchment for damage prevention (Fig. 2).

\section{METHODS}

Field work was conducted over the entire reaches of $3812 \mathrm{~m}$ including eight first order streams, two second order streams, and one third order stream between March and June, 2010, before summer monsoon season (Fig. 1 and Table 1). In-stream woods dispersed within bankfull channels were targeted for the study. Here, bankfull stage was identified from the change in riparian vegetation or cross-sectional profile (e.g., the top of bank), as in the work of Cadol et al. (2009). Bankfull channel width was measured in $20 \mathrm{~m}$ intervals in each study reach.

LWD was divided into two types in this study: individual pieces and jams. An individual piece was defined as LWD with dimensions greater than $0.1 \mathrm{~m}$ in diameter and $1 \mathrm{~m}$ in length. A jam was defined as an accumulation of at least three LWD pieces. The mid-diameter and length of all individual and jam-forming woody debris pieces meeting the conditions were measured. The volumes of the individual pieces or those forming jams were calculated from the measured mid-diameter and length, assuming a cylindrical shape (Comiti et al., 2008; Cadol et al., 2009). For mixed sediment and LWD deposits, the volume was calculated from the measured geometric dimensions (i.e., width, length, and height), assuming a hexahedral shape (Piégay, 1993), with 0.7 (Ohuchi, 1987)

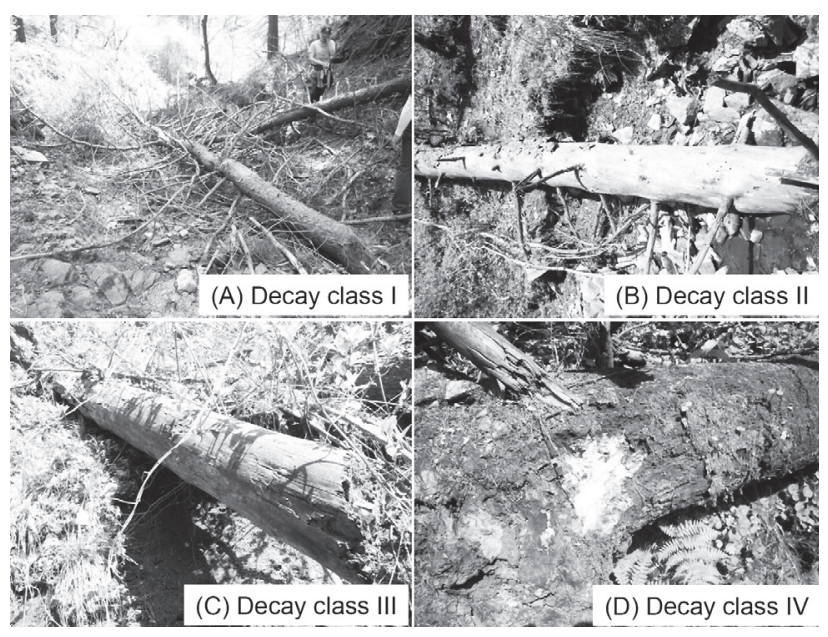

Fig. 3. Classification of LWD decay classes in this study: (A) class I; (B) class II; (C) class III; (D) class IV. applied as the porosity.

All individual LWD pieces and jams were classified into four decay classes based on the presence or condition of bark and branches. The decay classes were divided as follows: (I) hard piece with fresh bark having branches (Fig. 3A), (II) hard piece with loose bark having some branches (Fig. 3B), (III) only hard piece without bark and branches (Fig. 3C), and (IV) only soft piece without bark and branches (Fig. 3D).

To monitor the movement of LWD, aluminum tags were attached to 56 individual pieces in some sections in May 2010, and the movement status was checked twice per year, before (May) and after (November) the rainy season.

\section{RESULTS}

\section{LWD load}

Total volume and number of LWD per unit channel area were $0.009 \mathrm{~m}^{3} / \mathrm{m}^{2}$ and 0.04 pieces $/ \mathrm{m}^{2}$ in the first order stream, $0.007 \mathrm{~m}^{3} / \mathrm{m}^{2}$ and 0.03 pieces $/ \mathrm{m}^{2}$ in the second order stream, and $0.004 \mathrm{~m}^{3} / \mathrm{m}^{2}$ and 0.01 pieces $/ \mathrm{m}^{2}$ in the third order stream, respectively, decreasing as the order increased (Fig. 4A).

The volume and number of LWD jams per unit channel area were $0.001 \mathrm{~m}^{3} / \mathrm{m}^{2}$ and 0.0008 no. $/ \mathrm{m}^{2}$ in the first order stream, $0.003 \mathrm{~m}^{3} / \mathrm{m}^{2}$ and $0.0013 \mathrm{no} . / \mathrm{m}^{2}$ in the second order stream, and $0.002 \mathrm{~m}^{3} / \mathrm{m}^{2}$ and $0.0011 \mathrm{no} . / \mathrm{m}^{2}$ in the third order stream, respectively, with the second order stream being the highest, followed by the third
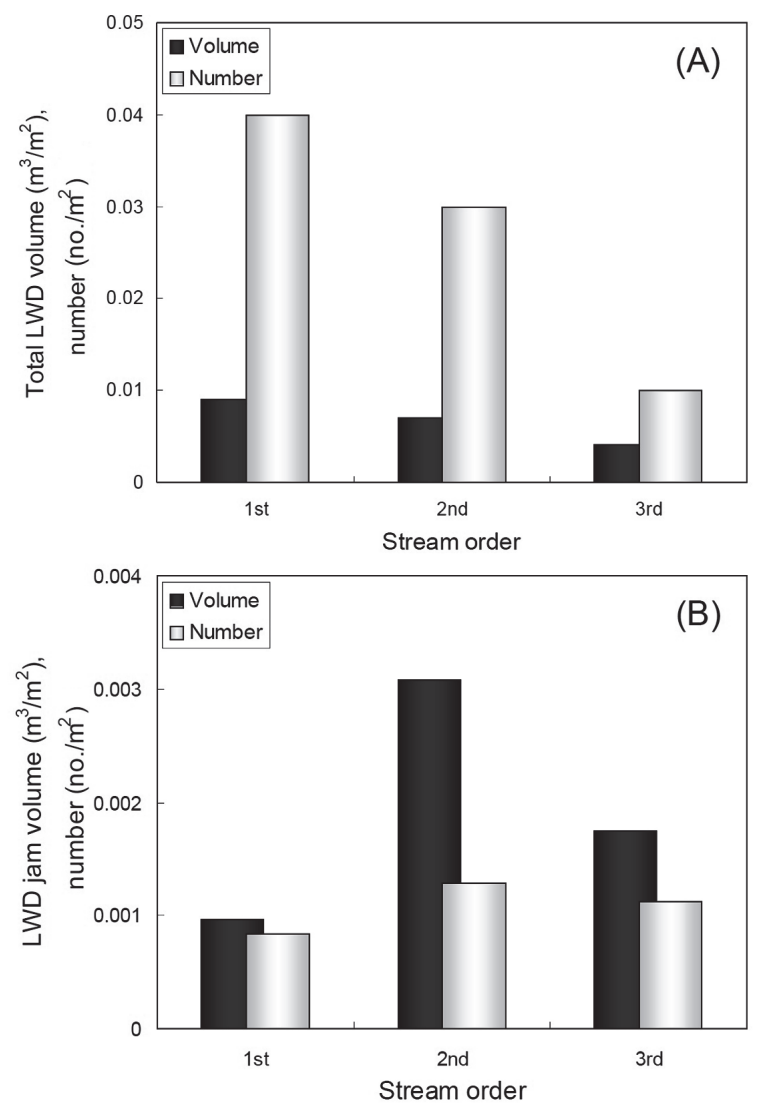

Fig. 4. LWD volume and number for each stream order: (A) LWD; (B) LWD jam. 
order stream, and then the first order stream (Fig. 4B). The ratio of jams in the entire LWD volume was 11\% in the first order stream, $43 \%$ in the second order stream, and $50 \%$ in the third order stream, increasing as the stream order increased.

\section{LWD geometric dimensions}

Figs. 5 and 6 show the ratio of LWD length to channel width and the relationship between mid-diameter and length for each steam order, respectively. The distribution width gradually decreased as the stream order increased for LWD piece length/channel width ratio, with 95\% being lower than 0.5 in the third order stream. The average value ( \pm standard deviation (SD)) was 0.61 ( \pm $0.62)$ in the first order stream, $0.33( \pm 0.34)$ in the second order stream, and $0.16( \pm 0.14)$ in the third order stream (Fig. 5). The relationship between LWD middiameter and length analyzed in consideration of conifer-
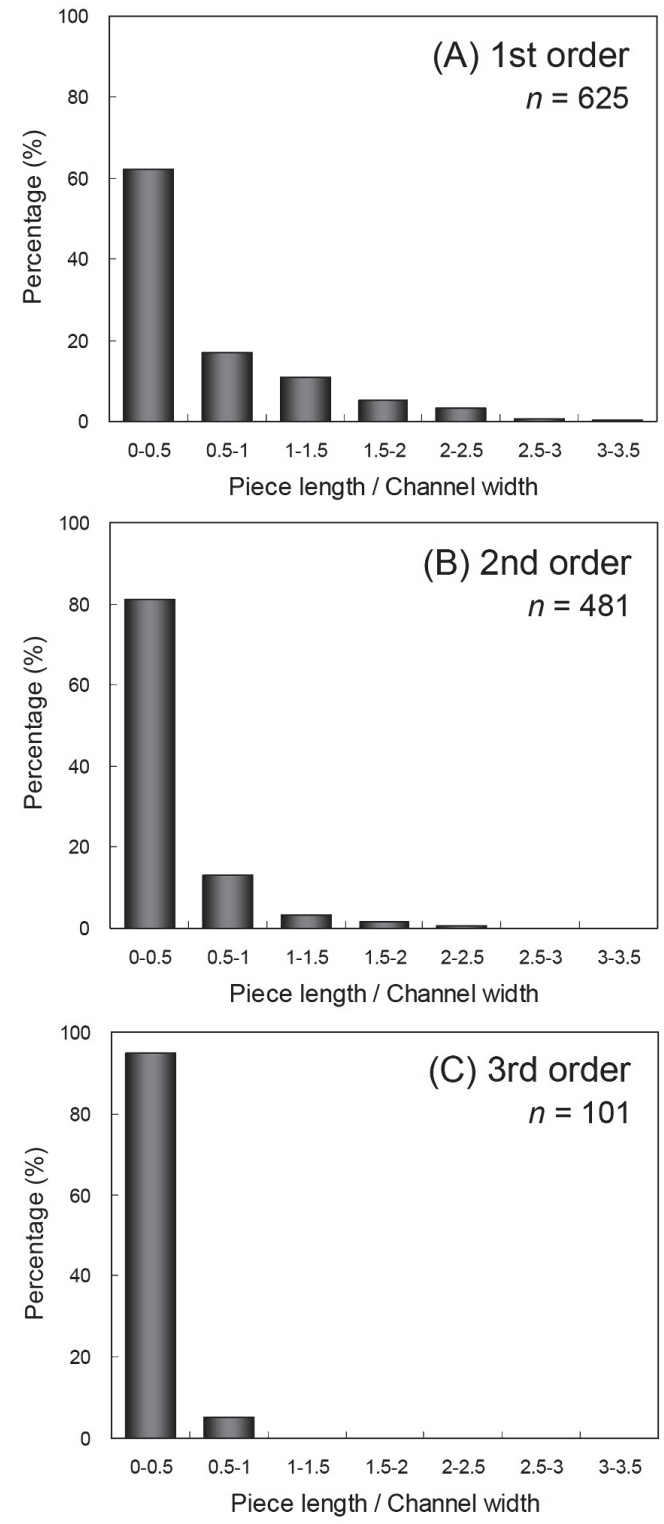

Fig. 5. Distribution of the piece length/channel width ratio for each stream order: (A) first order; (B) second order; (C) third order.
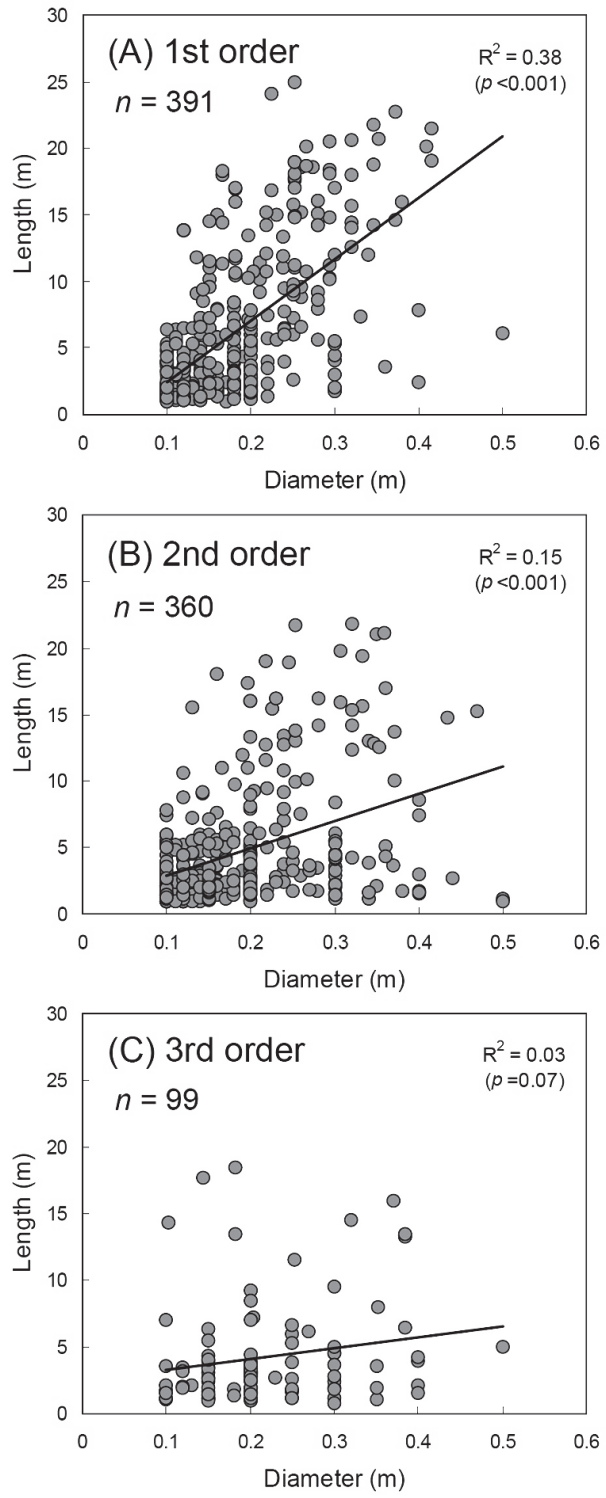

Fig. 6. Relationship between length and mid-diameter for coniferous and natural pieces for each stream order: (A) first order; (B) second order; (C) third order.

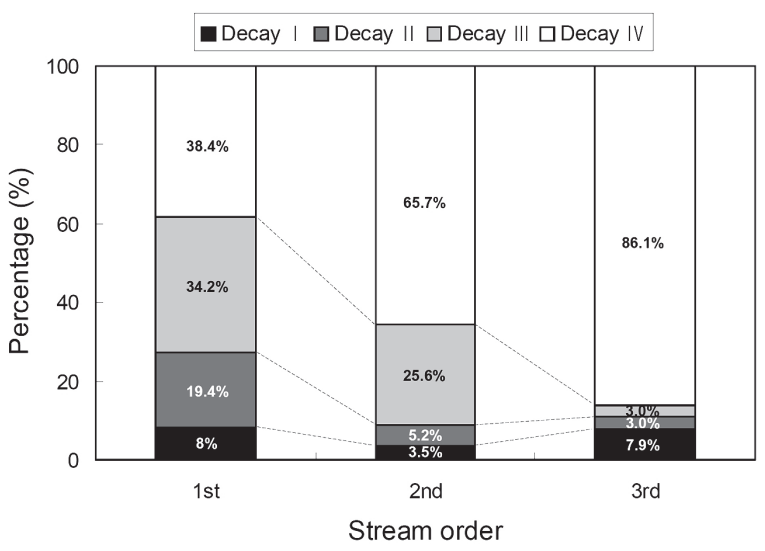

Fig. 7. Percentage of LWD decay classes for each stream order. 
ous and natural wood pieces showed that the length for identical diameter became relatively shorter as the stream order increased (Fig. 6). In other words, although the average diameter $( \pm$ SD) was identically $0.2( \pm 0.1) \mathrm{m}$ in all the orders, average length differed at $6.0( \pm 5.5) \mathrm{m}$ in first order stream, $4.6( \pm 4.4) \mathrm{m}$ in the second order stream, and $4.2( \pm 3.9) \mathrm{m}$ in the third order stream. While the correlation was relatively high in the first order stream (Fig. 6A), it was low in the second stream (Fig. $6 \mathrm{~B}$ ) and third order stream (Fig. 6C).

\section{LWD decay class}

The ratio of decay class I was higher in the third order stream than in the second order stream, but class I to III gradually decreased as the stream order increased (Fig. 7 ). In contrast, decay class $\mathrm{IV}$ significantly increased as the stream order increased, consisting of $65.7 \%$ and $86.1 \%$ of the entire LWD in the second and third order streams, respectively.

\section{LWD mobilization}

Although no movement of LWD occurred between May 2010 and June 2013, movement caused by heavy rainstorm was confirmed between July 13 and July 15, 2013 (Fig. 8). Of the 56 tagged LWD pieces, 34 pieces moved, with the mobility of $60 \%$ in the first order stream, $56 \%$ in the second order stream, and $86 \%$ in the third order stream (Table 2). According to the data from the

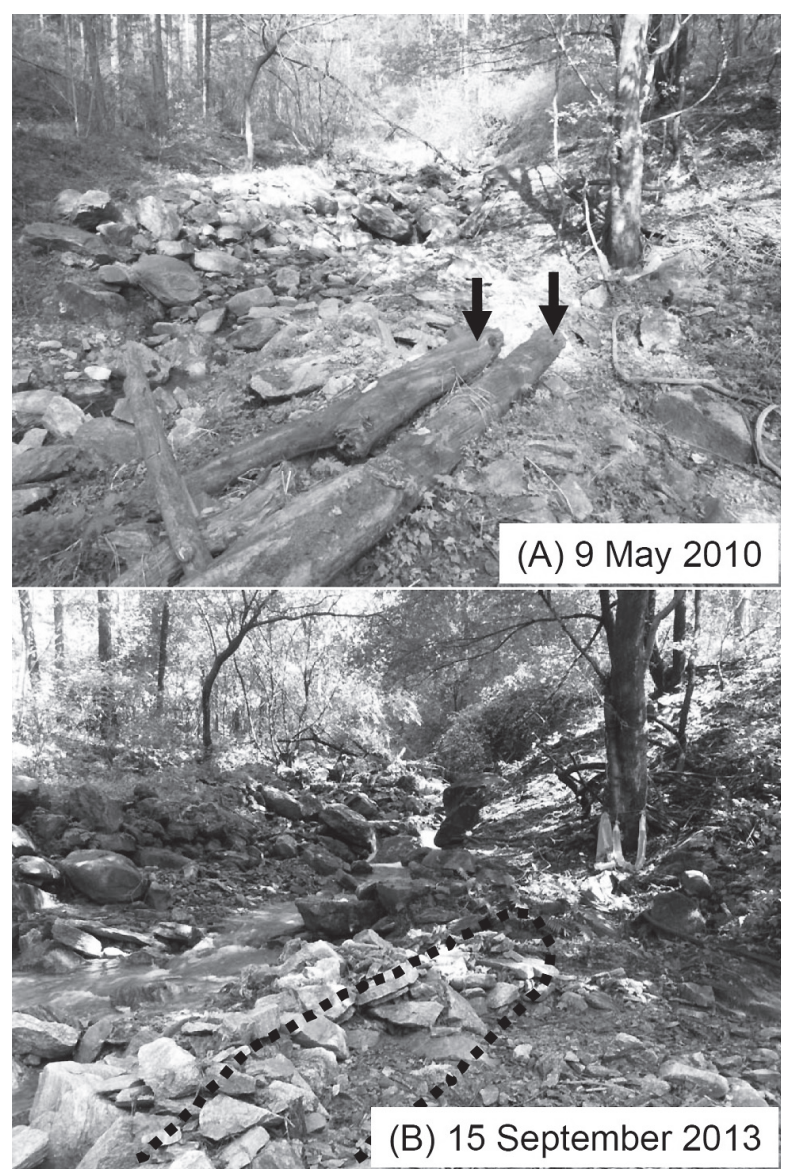

Fig. 8. LWD movement caused by 2013 heavy rainstorm event: (A) before the event (9 May 2010); (B) after the event (15 September 2013).
Table 2. Number of tagged and mobilized LWD pieces for each stream order

\begin{tabular}{cccc}
\hline Stream order & $\begin{array}{c}\text { Number of } \\
\text { tagged pieces }\end{array}$ & $\begin{array}{c}\text { Number of } \\
\text { moved pieces }\end{array}$ & Mobility (\%) \\
\hline 1st & 15 & 9 & 60 \\
2nd & 34 & 19 & 56 \\
3rd & 7 & 6 & 86 \\
\hline Total & 56 & 34 & 61 \\
\hline
\end{tabular}

Bukbang weather station, which was about $1.5 \mathrm{~km}$ away from the study area, the maximum 3-day rainfall during heavy rainstorm event was $263 \mathrm{~mm}$ in 2010 (10-12 September), $402 \mathrm{~mm}$ in 2011 (26-28 July), $181 \mathrm{~mm}$ in 2012 (20-22 August) and $501 \mathrm{~mm}$ in 2013 (13-15 July).

A t-test for validating LWD mobilization according to piece length/channel width ratio showed statistically indifference between the mobile LWD pieces and immobile LWD pieces at the $5 \%$ significance level. For the mobile 15 LWD pieces, which was visually confirmed, the traveled distance decreased as the piece length/channel width ratio increased, with the range being $20 \mathrm{~m}$ in the first order stream, 1 to $46 \mathrm{~m}$ in the second order stream, and 91 to $96 \mathrm{~m}$ (pieces trapped by buttress check dam) in the third order stream (Fig. 9).

\section{DISCUSSION}

The total volume of LWD was highest in the first order stream and decreased in the second order stream, and then the third order stream (Fig. 4A). Generally, total volume of LWD is large in low order streams and decreases downstream (Keller and Swanson, 1979; Lienkaemper and Swanson, 1987; Robison and Beschta, 1990). In headwater streams (i.e., first and second order streams), LWD generated by blowdown, disease, bank erosion and landslides directly enters the channels that are coupled to adjacent hillslopes (Keller and Swanson, 1979; Nakamura et al., 2000). These streams generally have narrow channel widths and lack sufficient discharge to move the LWD or fallen trees, therefore LWD movement is limited (Swanson and Lienkaemper, 1978). Moreover, the boulders scattered around the channel bed act as obstructions (Kim et al., 2008), trapping significant amounts of LWD behind them (Nakamura and Swanson, 1994; Miyabuchi et al., 1999; Seo et al., 2011). Fallen trees in the streams also capture LWD pieces (Shimizu, 2009). In headwater streams, the main mechanism to move LWD is a debris flow, and thus, if debris flow does not occur, LWD remains within the stream channel (Keller and Swanson, 1979).

On the other hand, since stream channels become wider and deeper as stream order increased, higher order streams have sufficient flow to redistribute or move LWD (Swanson and Lienkaemper, 1978; Bilby and Ward, 1989). In larger or higher order streams, LWD piece length is shorter than bankfull width (Keller and Swanson, 1979; Gurnell et al., 2002), and the flow with higher discharge 
makes it easy for LWD to move. Moreover, as channel bed slope becomes more gradual, geomorphic features such as floodplains or secondary channels develop (Gurnell et al., 2002), limiting direct input of LWD by hillslope processes.

Eventually, lower order streams are transport limited, whereas higher order streams are supply limited. Such trends were also well represented in the study area. The changes in channel width (Table 1) and relative length (Figs. 5 and 6) of LWD according to stream order supported the results that the potential mobility of LWD increased as the stream order increased, and thereby storage volume decreased.

The volume and formation frequency of LWD jams was highest in the second order stream and lowest in the first order stream (Fig. 4B). Moreover, the ratio of jams of the entire LWD volume was $11 \%$ in the first order stream, $43 \%$ in the second order stream, and $50 \%$ in the third order stream, increasing with the progression to higher orders. Such results indicated that most LWD were dispersed as individual pieces in the first order stream, and approximately half exist as jams in the second and third order streams in the study area. As previously mentioned, however, there was a greater possibility for LWD to form jam as it was easier for LWD to be deposited in low order streams than in high order streams owing to the presence of channel obstructions such as boulders and fallen trees, along with narrow channel width. In a study of a fourth order catchment of the Saru River in Japan, Shimizu (2009) confirmed 23 (92\%) of the 25 LWD jams were distributed in the first and second order streams, and identified the blockage of stream due to narrow channel width as the cause. Such jams are repeatedly formed or destroyed as LWD move downstream within the stream network (Shimizu, 2009). LWD moved to high order streams by debris flow stays in the form of jam in various deposition areas (e.g., bars, floodplains), and cannot be easily moved unless a large flood occurs (Wyżga and Zawiejska, 2005). Hence, the distribution or volume of LWD jams within the stream network is assumed to be characterized by the frequency or magnitude of debris flow for low order streams and floods for high order streams.

LWD is fragmented as it crashes with rocks in the channel bed or on the channel bank as it moves downstream (Bisson and Bilby, 1998; Wipfli et al., 2007). LWD decay rate is faster in small pieces than in larger pieces, depending on the size such as length and diameter (Harmon et al., 1986). The relationship between middiameter and length of LWD according to the stream order for coniferous and natural pieces shown in this study pertained to fragmentation caused by movement downstream (Fig. 6), which may be why the rate of decayed pieces increased downstream (Fig. 7). An exception is the significantly higher ratio of decay class I in the third order stream than the second order stream. This higher ratio is due to a large input of LWD from a shallow landslide in the summer of 2009 at the hillslope adjacent to the third order stream (Fig. 10).

LWD mobility was higher in the third order stream than in the first and second order streams (Table 2). Traveled distance was inversely related to the piece length/channel width ratio and relatively increased more in the high order streams than in the low order streams (Fig. 9). This difference seems to be related to the decrease of piece length/channel width ratio caused by LWD fragmentation or increase of channel width as LWD moved downstream (Figs. 5 and 6). In general, the mobility of LWD is determined by the relative dimensions to channel size; that is, by the ratio of piece diameter to channel depth or piece length to channel width (Braudrick and Grant, 2000; Martin and Benda, 2001; Haga et al., 2002; Gurnell et al., 2002; Iroumé et al., 2015). LWD can move downstream easier if the piece length is shorter than the channel width (Lienkaemper and Swanson, 1987; Nakamura and Swanson, 1993). Similar to the results of the present study, Martin and Benda (2001) reported most LWD moved downstream when the piece length/channel width ratio was below 1 and also mentioned that the traveled distance of LWD might increase as the basin area increases. Moreover, Iroumé et al. (2015) reported that for 96\% of the mobile

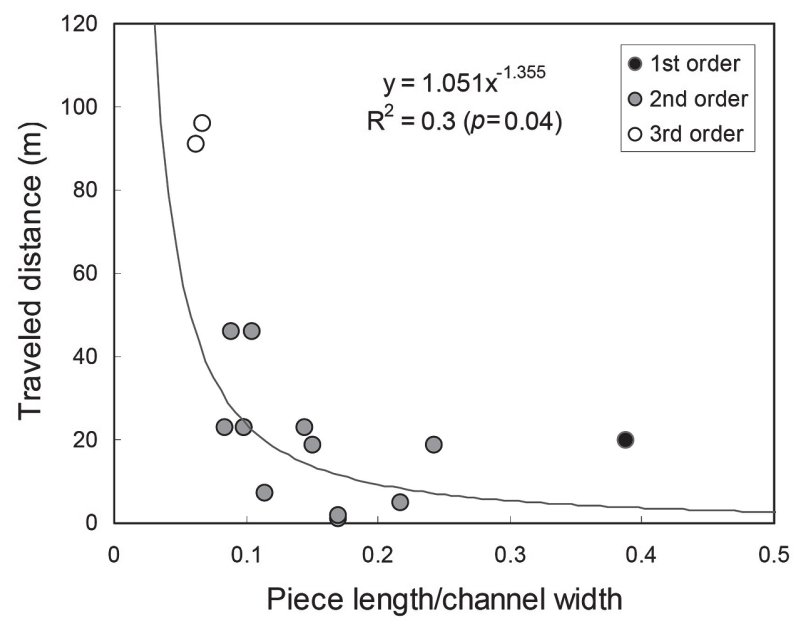

Fig. 9. Relationship between traveled distance and the piece length/channel width ratio.

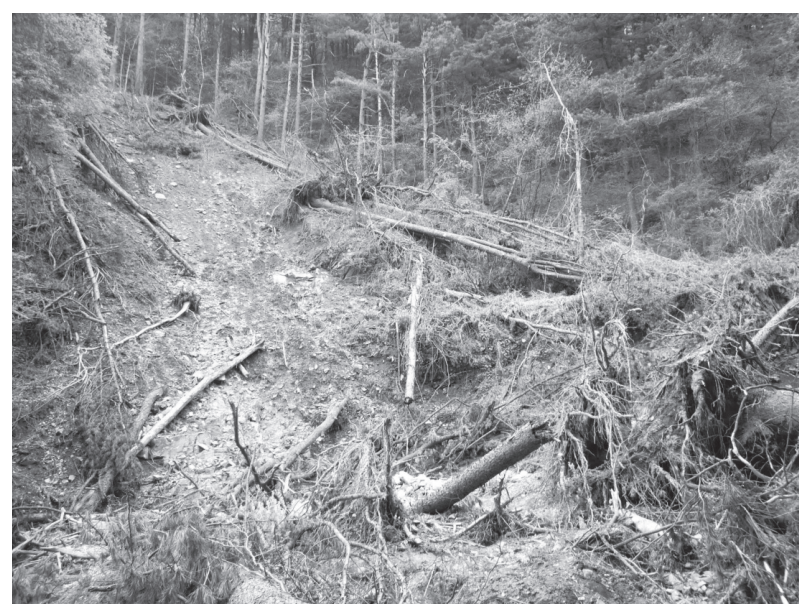

Fig. 10. LWD generation from shallow landslide at the hillslope adjacent to the third order stream. 
LWD piece length was shorter than bankfull channel width from field observation in the mountain catchments of southern Chile. The results of the present study were supported by the aforementioned previous studies and emphasize that LWD piece length/channel width ratio was a very important factor in determining traveled distance. No statistically meaningful difference was found in the piece length/channel width ratio between mobile and immobile LWD, suggesting the ratio was unrelated to the initial conditions determining LWD movement. Braudrick and Grant (2000) reported that the ratio of piece diameter to flow depth was more important than the ratio of piece length to channel width as the threshold of LWD movement "provided that piece length is less than channel width".

\section{CONCLUSION}

The present study investigated the distribution and mobilization of LWD in first, second and third order streams within the experimental forests of Kangwon National University located in Hongchun-gun of Gangwon province of South Korea, and clearly identified the characteristics of LWD according to the stream order. As in previous studies, low order streams were suggested to be transport limited, whereas high order streams were supply limited. The importance of the relative change in LWD length in the stream network, especially as a traveldistance controlling factor, was suggested. Hence, countermeasures focused on the movement and influence by the geometric dimensions of LWD are required for forest management and effective reduction of LWD-induced damage.

\section{ACKNOWLEDGEMENTS}

This study was conducted with the support of Forest Science \& Technology Projects (Project No. S111214L050110) provided by the Korea Forest Service, Republic of Korea.

\section{REFERENCES}

Abbe, T. B. and D. R. Montgomery 1996 Large woody debris jams, channel hydraulics and habitat formation in large rivers. Regul. Rivers: Res. Mgmt., 12: 201-221

Andreoli, A., F. Comiti and M. A. Lenzi 2007 Characteristics, distribution and geomorphic role of large woody debris in a mountain stream of the Chilean Andes. Earth Surf. Process. Landf., 32: 1675-1692

Bilby, R. E. and J. W. Ward 1989 Changes in characteristics and function of woody debris with increasing size of streams in western Washington. Trans. Am. Fish. Soc., 118: 368-378

Bisson, P. A. and R. E. Bilby 1998 Organic matter and trophic dynamics. In "River Ecology and Management", eds. by R. J. Naiman and R. E. Bilby, Springer, New York, USA, pp. 373-398

Braudrick, C. A. and G. E. Grant 2000 When do logs move in rivers? Water Resour. Res., 36: 571-583

Cadol, D., E. Wohl, J. R. Goode and K. L. Jaeger 2009 Wood distribution in neotropical forested headwater streams of La Selva, Costa Rica. Earth Surf. Process. Landf., 34: 1198-1215

Chen, S.C., Y. C. Chao and H. C. Chan 2013 Typhoon-dominated influence on wood debris distribution and transportation in a high gradient headwater catchment. J. Mt. Sci., 10: 509-521

Choi, K. 1986 Landslides occurrence and its prediction in Korea. Ph.D. dissertation. Kangwon National University, Chuncheon, Korea (in Korean with English abstract)

Chun, K. W., M. S. Kim, W. G. Park and T. Ezaki 1997 Characteristics of channelbed and woody debris on mountainous stream. J. Korean For. Soc., 86: 69-79 (in Korean with English abstract)

Chun, K. W., S. W. Kim, S. M. Kwon, Y. H. Lim, K. J. Yeom and T. Ezaki 2010 Field application of small woody check dam (III): Characteristics of channel bed variation in 2010. J. Res. For. Kangwon Nat'l Univ., 30: 1-8 (in Korean with English abstract)

Comiti, F., A. Andreoli, M. A. Lenzi and L. Mao 2006 Spatial density and characteristics of woody debris in five mountain rivers of the Dolomites (Italian Alps). Geomorphology, 78: 44-63

Comiti, F., A. Andreoli, L. Mao and M. A. Lenzi 2008 Wood storage in three mountain streams of the Southern Andes and its hydro-morphological effects. Earth Surf. Process. Landf., 33: 242-262

Curran, J. H. and E. E. Wohl 2003 Large woody debris and flow resistance in step-pool channels, Cascade Range, Washington. Geomorphology, 51: 141-157

Fausch, K. D. and T. G. Northcote 1992 Large woody debris and salmonid habitat in a small coastal British Columbia stream. Can. J. Fish. Aquat. Sci., 49: 682-693

Faustini, J. M. and J. A. Jones 2003 Influence of large woody debris on channel morphology and dynamics on steep, boulder-rich mountain streams, western Cascade, Oregon. Geomorphology, 51: $187-206$

Gurnell, A. M., H. Piégay, F. J. Swanson and S. V. Gregory 2002 Large wood and fluvial processes. Freshw. Biol., 47: 601-619

Haga, H., T. Kumagai, K. Otsuki and S. Ogawa 2002 Transport and retention of coarse woody debris in mountain streams: An in situ field experiment of log transport and a field survey of coarse woody debris distribution. Water Resour. Res., 38: 1126

Harmon, M. E., J. F. Franklin, F. J. Swanson, P. Sollins, S. V. Gregory, J. D. Lattin, N. H. Anderson, S. P. Cline, N. G. Aumen, J. R. Sedell, G. W. Lienkaemper, K. Jr. Cromack and K. W. Cummins 1986 Ecology of coarse woody debris in temperate ecosystems. Adv. Ecol. Res., 15: 133-302

Hassan, M. A., D. L. Hogan, S. A. Bird, C. L. May, T. Gomi and D. Campbell 2005 Spatial and temporal dynamics of wood in headwater streams of the Pacific Northwest. J. Am. Water Resour. Assoc., 41: 899-919

Hyatt, T. L. and R. J. Naiman 2001 The residence time of large woody debris in the Queets River, Washington, USA. Ecol. Appl., 11: 191-202

Inoue, M. and S. Nakano 1998 Effects of woody debris on the habitat of juvenile masu salmon (Oncorhynchus masou) in northern Japanese streams. Freshw. Biol., 40: 1-16

Iroumé A., L. Mao, A. Andreoli and H. Ulloa 2015 Large wood mobility in mountain rivers, Chile. In "Engineering Geology for Society and Territory - Volume 3 (River Basins, Reservoir Sedimentation and Water Resources)", eds. by G. Lollino, M. Arattano, M. Rinaldi, O. Giustolisi, J. -C. Marechal and G. E. Grant, Springer International Publishing, Switzerland, pp. 143-145

Ishikawa, Y. 2006 Disaster caused by large woody debris and forest. Shinrin Kagaku, 47: 28-32 (in Japanese)

Keller, E. A. and F. J. Swanson 1979 Effects of large organic material on channel form and fluvial processes. Earth Surf. Process., 4: $361-380$

Kim, S. W., K. Goto, K. W. Chun and T. Marutani 2008 Influence of bedrock projections and large rocks on sediment transport in a mountainous gorge channel. J. Jpn. Soc. Erosion Control Eng., 61: 3-11 (in Japanese with English abstract)

Kim, S. W., K. W. Chun, K. N. Kim, C. M. Park and T. Marutani 2011 Restoration method of small stream using artificial step-pool sequences. J. Korean Env. Res. Tech., 14: 11-23 (in Korean with English abstract)

Korea Forest Service 2013 Statistical yearbook of forestry. 
Korea Forest Service, Daejeon (Korea)

Lee, S. Y., K. W. Chun, K. W. Jun, M. W. Lee, M. S. Kim, H. J. Lee, Y. J. Park, Y. J. Kim, C. G. Kwon and C. H. Yeom 2007 Effect of the leaving of thinning slash on forest disaster (Korea Forest Service Res. Rep.). Korea Forest Service, Daejeon (in Korean)

Lienkaemper, G. W. and F. J. Swanson 1987 Dynamics of large woody debris in old-growth Douglas-fir forests. Can. J. For. Res., 17: 150-156

Marston, R. A. 1982 The geomorphic significance of log steps in forest streams. Ann. Assoc. Am. Geogr., 72: 99-108

Martin, D. J. and L. E. Benda 2001 Patterns of instream wood recruitment and transport at the watershed scale. Trans. Am. Fish. Soc., 130: 940-958

May, C. L. and R. E. Gresswell 2003 Large wood recruitment and redistribution in headwater streams in the Southern Oregon Coast Range, USA. Can. J. For. Res., 33: 1352-1362

Meleason, M. A., R. Davies-Colley, A. Wright-Stow, J. Horrox and K. Costley 2005 Characteristics and geomorphic effect of wood in New Zealand's native forest streams. Internat. Rev. Hydrobiol., 90: 466-485

Miyabuchi, Y., A. Shimizu and Y. Ogawa 1999 Storage of woody debris and sediment in a mountain stream, northern Kyushu, southern Japan. J. Jpn. Soc. Erosion Control Eng., 52: 21-27 (in Japanese with English abstract)

Montgomery, D. R., J. M. Buffington, R. D. Smith, K. M. Schmidt and G. Pess 1995 Pool spacing in forest channels. Water Resour. Res., 31: 1097-1105

Mosley, M. P. 1981 The influence of organic debris on channel morphology and bedload transport in a New Zealand forest stream. Earth Surf. Process. Landf., 6: 571-579

Nakamura, F. and F. J. Swanson 1993 Effects of coarse woody debris on morphology and sediment storage of a mountain stream system in western Oregon. Earth Surf. Process. Landf., 18: 43-61

Nakamura, F. and F. J. Swanson 1994 Distribution of coarse woody debris in a mountain stream, western Cascade Range, Oregon. Can. J. For. Res., 24: 2395-2403

Nakamura, F., F. J. Swanson and S. M. Wondzell 2000 Disturbance regimes of stream and riparian systems: A disturbance-cascade perspective. Hydrol. Process., 14: 2849-2860

Ohuchi, Y. 1987 Timber measurement (Bassaibokunosokutei). In "Forest Measurement Lecture", ed. by S. Ohsumi, Yokendo,
Tokyo, pp. 28-47 (in Japanese)

Piégay, H. 1993 Nature, mass and preferential sites of coarse woody debris deposits in the lower ain valley (Mollon reach), France. Regul. Rivers: Res. Mgmt., 8: 359-372

Piégay, H. and A. M. Gurnell 1997 Large woody debris and river geomorphological pattern: examples from S. E. France and S. England. Geomorphology, 19: 99-116

Richmond, A. D. and K. D. Fausch 1995 Characteristics and function of large woody debris in subalpine Rocky Mountain streams in northern Colorado. Can. J. Fish. Aquat. Sci., 52: 17891802

Robison, E. G. and R. L. Beschta 1990 Coarse woody debris and channel morphology interactions for undisturbed streams in southeast Alaska, USA. Earth Surf. Process. Landf., 15 149-156

Seo, J. I., K. W. Chun, M. S. Kim, K. J. Yeom, J. H. Lee and M. Kimura 2011 Longitudinal pattern of large wood distribution in mountain streams. J. Korean For. Soc., 100: 52-61 (in Korean with English abstract)

Shimizu, O. 2009 Wood debris transport processes and formation and failure of wood debris dams in mountain channel networks. J. Jpn. Soc. Erosion Control Eng., 62: 3-13 (in Japanese with English abstract)

Swanson, F. J. and G. W. Lienkaemper 1978 Physical consequences of large organic debris in Pacific Northwest streams (Gen Tech Rep PNW-69). US Department of Agriculture Forest Service Pacific Northwest Forest and Range Experiment Station, Portland, OR

Wilcox, A. C. and E. E. Wohl 2006 Flow resistance dynamics in step-pool stream channels: 1. Large woody debris and controls on total resistance. Water Resour. Res., 42: W05418

Wipfli, M. S., J. S. Richardson and R. J. Naiman 2007 Ecological linkages between headwaters and downstream ecosystems: Transport of organic matter, invertebrates, and wood down headwater channels. J. Am. Water Resour. Assoc., 43: 72-85

Wohl, E. E., S. Madsen and L. MacDonald 1997 Characteristics of log and clast bed-steps in step-pool streams of northwestern Montana, USA. Geomorphology, 20: 1-10

Wyżga, B. and J. Zawiejska 2005 Wood storage in a wide mountain river: case study of the Czarny Dunajec, Polish Carpathians. Earth Surf. Process. Landf., 30: 1475-1494 